\title{
Automation of Filling Cryogenic Vessels with Perlite
}

Jan Štěrba, Valérie Černohlávková, Josef Soukup

Faculty of Production Technology and Management, J. E. Purkyne University in Usti nad Labem. Pasteurova 3334/7, 400 01 Usti nad Labem. Czech Republic.E-mail: sterba@fvtm.ujep.cz; cernohlavkova@fvtm.ujep.cz; soukupj@fvtm.ujep.cz

Liquefied technical gases are used in almost all sectors, regardless of whether this is industrial application (engineering, food processing, electronics), as well as in health and other sectors. These gases are kept in cryogenic vessels. A cryogenic vessel is a two-walled vessel where the inner vessel is used to keep the gas, the outer vessel is used as packaging, and the space between the inner and outer vessels is thermally insulated. The insulation must have such parameters to ensure that the stored cryogenic gases remain in the liquefied state for the longest possible time. Various materials and methods are used to insulate the vessels, but the most common insulation for cryogenic vessels is perlite insulation in combination with vacuum. The problems of isolation of cryogenic vessels using perlite are dealt with by only a few specialized companies that produce vessels for liquefied technical (cryogenic) gases.

Keywords: cryogenic vessels, perlite, vacuum, cryogenic technical gases

\section{Acknowledgements}

The article originated under the support of the grant SGS UJEP.

\section{References}

[1] BARRON, R. (1966). Cryogenic Systems. New York, McGraw Hill.

[2] OTA, J. (2004). Kryogenní technika a její aplikace (Cryogenic technology and its applications). ČVUT Praha, Fakulta strojní, Praha.

[3] KINZER, G., R., jr. (1963). Thermal Conductivity of Expanded Perlite Cryogenic Fill Insulation. ASHRAE Journal, February, 1963 and 1967

[4] CHLUMSKÝ, V. (1971). Technika chlazení (Technical cooling). SNTL Praha.

[5] URBAN, J. (1964). Pneumatická doprava (Pneumatic transport). SNTL Praha, Praha.

[6] SOUKUP, J. (1990). Nové způsoby odstraňování odpadi̊ (New waste disposal methods). 134 pages, VÚVA Praha, Praha, ISBN 80-85124-06-8

[7] SKOČILASOVÁ, B., SKOČILAS, J. (2013). Simulation of liquid flow in pipe. Manufacturing Technology, vol. 13, no 4, p542-547, ISSN 1213-2489 